\begin{tabular}{|c|l|}
\hline Title & $\begin{array}{l}\text { Quantification of intracellular and extracellular prostanoids stimulated by A 23187 by liquid } \\
\text { chromatography /electrospray ionization tandem mass spectrometry }\end{array}$ \\
\hline Author(s) & $\begin{array}{l}\text { Furugen, A yako; Y amaguchi, Hiroaki; Tanaka, Nobuaki; Ito, Hajime; Miy amori, Kazuaki; Fujikawa, A suka; } \\
\text { Takahashi, Natsuko; Ogura, Jiro; Kobay ashi, Masaki; Y amada, Takehiro; Mano, Nariy asu; Iseki, Ken }\end{array}$ \\
\hline Citation & $\begin{array}{l}\text { Journal of chromatography. B, A nalytical technologies in the biomedical and life sciences, 879(30), 3378-3385 } \\
\text { https:/doi.org/10.1016/.jchromb.2011.09.003 }\end{array}$ \\
\hline Issue Date & 2011-11-15 \\
\hline Doc URL & http:/hdl.handle.net/2115/50396 \\
\hline Type & article(author version) \\
\hline File Information & Yamaguchi_H_03.pdf \\
\hline
\end{tabular}

Instructions for use 


\section{Quantification of intracellular and extracellular prostanoids stimulated by A23187 by liquid chromatography/electrospray ionization tandem mass spectrometry}

Ayako Furugen ${ }^{\mathrm{a}}$, Hiroaki Yamaguchi ${ }^{\mathrm{a}}$, Nobuaki Tanaka ${ }^{\mathrm{a}}$, Hajime Ito ${ }^{\mathrm{a}}$, Kazuaki Miyamori $^{\mathrm{a}}$, Asuka Fujikawa ${ }^{\mathrm{a}}$, Natsuko Takahashi ${ }^{\mathrm{b}}$, Jiro Ogura ${ }^{\mathrm{a}}$, Masaki Kobayashi ${ }^{\mathrm{a}}$, Takehiro Yamada ${ }^{\mathrm{c}}$, Nariyasu Mano ${ }^{\mathrm{d}}$, Ken Iseki $^{\mathrm{a},{ }^{*}}$

${ }^{a}$ Laboratory of Clinical Pharmaceutics \& Therapeutics, Division of Pharmasciences, Faculty of Pharmaceutical Sciences, Hokkaido University, Kita-12-jo, Nishi-6-chome, Kita-ku, Sapporo 060-0812, Japan

${ }^{\mathrm{b}}$ Graduate School of Medicine, Hokkaido University, Sapporo 060-8638, Japan 'Department of Pharmacy, Hokkaido University Hospital, Sapporo 060-8648, Japan ${ }^{\mathrm{d}}$ Department of Pharmaceutical Sciences, Tohoku University Hospital, Sendai 980-8574, Japan

*To whom correspondence should be addressed.

Ken Iseki, Ph.D., Laboratory of Clinical Pharmaceutics \& Therapeutics, Division of Pharmasciences, Faculty of Pharmaceutical Sciences, Hokkaido University Kita-12-jo, Nishi-6-chome, Kita-ku, Sapporo 060-0812, Japan

Tel/Fax: +81-11-706-3770

E-mail address: ken-i@pharm.hokudai.ac.jp 


\begin{abstract}
Prostanoids are bioactive substances that contribute to various biological and pathological processes. To evaluate both extracellular and intracellular levels of prostanoids at the same time, we developed methods for quantification of extracellular and intracellular levels of prostanoids, including prostaglandin $\mathrm{E}_{2}\left(\mathrm{PGE}_{2}\right), \mathrm{PGD}_{2}, \mathrm{PGF}_{2 \alpha}$, 6-keto $\mathrm{PGF}_{1 \alpha}$, and $\mathrm{TXB}_{2}$, in cultured cells using liquid chromatography/tandem mass spectrometry (LC/MS/MS), and we validated the LC/MS/MS methods. A solid-phase extraction cartridge was used for extraction of prostanoids. The prostanoids were separated by a $\mathrm{C}_{18}$ column with an isocratic flow of acetonitrile/water/acetic acid (40:60:0.1, v/v/v). Calibration curves of extracellular measurement for the prostanoids were linear in the range from 0.1 to $100 \mathrm{ng} / \mathrm{mL}\left(r^{2}>0.999\right)$, and those of intracellular measurement were linear in the range from 0.05 to $50 \mathrm{ng}\left(r^{2}>0.999\right)$. Validation assessment showed that both methods of extracellular and intracellular measurements were highly reliable with good accuracy and precision. We also applied the methods to human airway epithelial Calu-3 cells and human lung adenocarcinoma epithelial A549 cells.
\end{abstract}

\title{
Keywords
}

Prostanoid; LC/MS/MS; intracellular measurement

\section{Abbreviations}

COX, cyclooxygenase; IS, internal standard; LC/MS/MS, liquid chromatography/tandem mass spectrometry; LLOQ, lower limit of quantification; MRM, multiple reaction monitoring; PG, prostaglandin; TX, thromboxane 


\section{Introduction}

Prostanoids, including prostaglandins and thromboxane, are important bioactive lipid mediators of various physiological and pathological processes [1-4]. For example, prostaglandin $\mathrm{E}_{2}\left(\mathrm{PGE}_{2}\right)$ is involved in inflammation, carcinogenesis, and immune modulation. Prostaglandin $\mathrm{D}_{2}\left(\mathrm{PGD}_{2}\right)$ also contributes to inflammation and immune modulation and is involved in induction of sleep. Prostaglandin $\mathrm{F}_{2 \alpha}\left(\mathrm{PGF}_{2 \alpha}\right)$ contributes to induction of parturition and contraction of smooth muscle. Furthermore, prostaglandin $\mathrm{I}_{2}\left(\mathrm{PGI}_{2}\right)$ has platelet anti-aggregating and vascular dilation effects. On the other hand, thromboxane $\mathrm{A}_{2}\left(\mathrm{TXA}_{2}\right)$ has platelet aggregation and vascular contraction effects. Since $\mathrm{PGI}_{2}$ and $\mathrm{TXA}_{2}$ have short half-life periods, they are non-enzymatically converted into 6-keto prostaglandin $\mathrm{F}_{1 \alpha}\left(6-\right.$ keto $\left.\mathrm{PGF}_{1 \alpha}\right)$ and $\mathrm{TXB}_{2}$, respectively. Prostanoids are biosynthesized from arachidonic acid via the arachidonic acid cascade. Arachidonic acid is released from the cell membrane into the cytoplasm by phospholipase $\mathrm{A}_{2}$ and then converted into $\mathrm{PGH}_{2}$ by cyclooxygenase (COX-1 and $\mathrm{COX}-2) . \mathrm{PGH}_{2}$ is further converted into $\mathrm{PGE}_{2}, \mathrm{PGD}_{2}, \mathrm{PGF}_{2 \alpha}, \mathrm{PGI}_{2}$, and $\mathrm{TXA}_{2}$ by each prostaglandin synthase. Prostanoids are secreted from the intracellular space into the extracellular space by a specific transport system and exert their biological effects in an autocrine or paracrine manner by binding to cell surface receptors. In addition to prostanoids synthesis, transport and inactivation mechanisms are thought to be important for controlling extracellular levels of prostanoids [1]. Therefore, in addition to extracellular levels of prostanoids, examination of intracellular profiles of prostanoids is important for understanding the mechanism for control of prostanoid secretion and signaling. Horton et al. reported intracellular measurement of $\mathrm{PGE}_{2}$ in mouse fibroblasts and macropharges by an enzyme immunoassay [5]. Lin et al. investigated extracellular 
and intracellular profiles of $\mathrm{PGE}_{2}$ level in mouse embryonic fibroblast cells by an enzyme immunoassay and revealed the functional importance of mouse multidrug resistance protein $4(\mathrm{mrp} 4)$ in the transport of $\mathrm{PGE}_{2}[6]$. However, little information is currently available on the relationship between extracellular and intracellular prostanoids levels.

Liquid chromatography/tandem mass spectrometry (LC/MS/MS) is a powerful technique because it has high sensitivity and high specificity and enables simultaneous analysis. Recently, the LC/MS/MS technique has been used for analysis of several eicosanoids including prostaglandins, thromboxane, and leukotrienes [7-19]. Although several groups have developed methods for analysis of prostaglandins in cell culture media, tissues or biological fluids using LC/MS/MS, to our knowledge, there are no reports of examination of both intracellular and extracellular levels of prostanoids using LC/MS/MS.

In this study, we developed a simple and robust analytical method using $\mathrm{LC} / \mathrm{MS} / \mathrm{MS}$ to measure intracellular and extracellular levels of five major prostanoids or their metabolites, $\mathrm{PGE}_{2}, \mathrm{PGD}_{2}, \mathrm{PGF}_{2 \alpha}$, 6-keto $\mathrm{PGF}_{1 \alpha}$, and $\mathrm{TXB}_{2}$. Using this method, we investigated the intracellular and extracellular levels of prostanoids in human airway epithelial Calu-3 cells and human lung adenocarcinoma epithelial A549 cells. It is reported that these cell lines have ability to produce prostanoids [7, 18]

\section{Materials and methods}

\subsection{Chemicals}

All prostanoids and deuterated prostanoids $\left(\mathrm{PGE}_{2}, \mathrm{PGD}_{2}, \mathrm{PGF}_{2 \alpha}, 6\right.$-keto $\mathrm{PGF}_{1 \alpha}$, $\mathrm{TXB}_{2}, \mathrm{PGE}_{2}-\mathrm{d}_{4}, \mathrm{PGD}_{2}-\mathrm{d}_{4}, \mathrm{PGF}_{2 \alpha}-\mathrm{d}_{4}, 6-$ keto $\mathrm{PGF}_{1 \alpha}-\mathrm{d}_{4}$, and $\left.\mathrm{TXB}_{2}-\mathrm{d}_{4}\right)$ were obtained 
from Cayman Chemical Co. (Ann Arbor, MI). A23187 and indomethacin were obtained from Sigma Aldrich (St. Louis, MO). All organic solvents and other chemicals were purchased from Wako (Tokyo, Japan). Bond Elut ${ }^{\circledR} \mathrm{C} 18$ solid-phase extraction (SPE) cartridges $(100 \mathrm{mg} / 1 \mathrm{~mL})$ were obtained from Agilent Technologies (Santa Clara, CA).

\section{$2.2 \mathrm{LC} / \mathrm{MS} / \mathrm{MS}$}

Chromatographic separation was carried out using a Shimadzu Prominance 20A System (Shimadzu, Kyoto, Japan). A Shiseido CAPCELL PAK C18 MGII column $(2.0 \times 150 \mathrm{~mm}, 5 \mu \mathrm{m})$ was used with an isocratic flow of acetonitrile/water/acetic acid $(40: 60: 0.1, \mathrm{v} / \mathrm{v} / \mathrm{v})$ at a flow rate of $0.2 \mathrm{~mL} / \mathrm{min}$, and column temperature was maintained at $40^{\circ} \mathrm{C}$. The injection volume was $10 \mu \mathrm{L}$. Negative ion electrospray tandem mass spectrometric analysis was carried out using an Applied Biosystems (Foster City, CA) API $3200^{\mathrm{TM}} \mathrm{LC} / \mathrm{MS} / \mathrm{MS}$ System at unit resolution with multiple reaction monitoring (MRM). MRM was performed by monitoring the transitions summarized in Table 1. Parameter settings were as follows: source temperature of $600^{\circ} \mathrm{C}$, spray voltage of $-4500 \mathrm{~V}$, curtain gas of $40 \mathrm{psi}$, ion source gas 1 of $40 \mathrm{psi}$, ion source gas 2 of $70 \mathrm{psi}$, collision gas of 5 arbitrary units, and dwell time of $200 \mathrm{~ms}$ per ion. Other parameters are shown in Table 1. Data were acquired and analyzed using Analyst software (version 1.5) (Applied Biosystems). Calibration curves were constructed by plotting peak area ratio (standard to internal standard) versus the nominal concentration and were fit using least-squares regression with $1 / \mathrm{x}$ weighting.

\subsection{Standards and calibration curve preparation for LC/MS/MS analysis}

Standard stock solutions containing mixtures of $\mathrm{PGE}_{2}, \mathrm{PGD}_{2}, \mathrm{PGF}_{2 \alpha}$, 6-keto 
$\mathrm{PGF}_{1 \alpha}$, and $\mathrm{TXB}_{2}$ were prepared in methanol $(10,50,100,500,1000,5000$, and 10000 $\mathrm{ng} / \mathrm{mL}$ ). The internal standard (IS) stock solution containing $500 \mathrm{ng} / \mathrm{mL}$ of $\mathrm{PGE}_{2}-\mathrm{d}_{4}$, $\mathrm{PGD}_{2}-\mathrm{d}_{4}, \mathrm{PGF}_{2 \alpha}-\mathrm{d}_{4}, 6-k e$ to $\mathrm{PGF}_{1 \alpha}-\mathrm{d}_{4}$, and $\mathrm{TXB}_{2}-\mathrm{d}_{4}$ was made in methanol. All solutions were stored at $-30^{\circ} \mathrm{C}$. Calibration solutions of prostanoids were prepared daily from stock solutions at concentrations of $0.1,0.5,1,5,10,50$, and $100 \mathrm{ng} / \mathrm{mL}(0.05,0.25,0.5$, $2.5,5,25$, and $50 \mathrm{ng}$ ) in $0.5 \mathrm{~mL}$ of blank medium (for extracellular measurement) or at concentrations of $0.05,0.25,0.5,2.5,5,25$, and $50 \mathrm{ng}$ in phosphate buffer described below (for intracellular measurement).

\subsection{Cell culture}

Human lung adenocarcinoma epithelial A549 cells were kept in Dulbecco's modified Eagle's medium (Sigma) with 10\% fetal bovine serum (ICN Biomedicals, Inc, Aurora, $\mathrm{OH}$ ) and 1\% penicillin-streptomycin (Sigma). Human airway epithelial Calu-3 cells were kept in DMEM/F12 (Gibco/Invitrogen, Grand Island, NY) with 10\% fetal bovine serum and $1 \%$ penicillin-streptomycin. All cells were grown at $37^{\circ} \mathrm{C}$ under $5 \%$ $\mathrm{CO}_{2}$. A549 cells $\left(2 \times 10^{5}\right.$ cells/well $)$ and Calu-3 cells $\left(1 \times 10^{6}\right.$ cells/well $)$ were seeded on 6-well plastic plates (Corning Costar Corp., Cambridge, MA). After the cells had grown to confluence (4 days for A549 cells and typically 7 days for Calu-3 cells), they were incubated overnight in serum-free medium before each experiment. For induction of the production of prostanoids, cells were then treated with $1 \mathrm{~mL}$ of serum-free medium containing $10 \mu \mathrm{M}$ A23187 for a designated time.

\subsection{Sample preparation}

For measurement of extracellular prostanoids, the medium was collected and 
stored at $-80^{\circ} \mathrm{C}$ until assay. The resulting cell monolayer was harvested for measurement of intracellular prostanoids. Sample preparation for extraction of intracellular prostanoids was based on the method of Lin et al. with modification [6]. Briefly, cells were rinsed twice with ice-cold PBS and scraped into ice-cold PBS. The cell suspension was centrifuged at $1,500 \times \mathrm{g}$ for $5 \mathrm{~min}$ at $4^{\circ} \mathrm{C}$ and the resulting pellet was stored at $-80^{\circ} \mathrm{C}$ until assay.

\subsection{Solid-phase extraction of prostnoids}

The solid-phase extraction (SPE) cartridge Bond Elut ${ }^{\circledR}$ C18 $(100 \mathrm{mg} / 1 \mathrm{~mL})$ (Agilent Technologies) was used for extraction of prostanoids. For extracellular assay, to each $500-\mu \mathrm{L}$ sample of culture medium, $5 \mu \mathrm{L}$ of a mixture of deuterated prostanoids (500 ng/mL each) as internal standards and $5 \mu \mathrm{L}$ of $10 \%$ dibutylhydroxytoluene (BHT) in ethanol for preventing peroxidation were added. For intracellular assay, to each frozen cell pellet (described above), $5 \mu \mathrm{L}$ of a mixture of deuterated prostanoids and 5 $\mu \mathrm{L}$ of $10 \%$ BHT were added and suspended in $0.5 \mathrm{~mL}$ of $0.1 \mathrm{M}$ phosphate buffer $(\mathrm{pH}$ 7.4, containing $1 \mathrm{mM}$ EDTA and $10 \mu \mathrm{M}$ indomethacin). The suspension was then sonicated for $30 \mathrm{sec}$ at $4^{\circ} \mathrm{C}$ and centrifuged at $15,000 \times g$ for $15 \mathrm{~min}$ at $4{ }^{\circ} \mathrm{C}$. The supernatant was used for measurement of intracellular prostanoids. The sample was adjusted to $\mathrm{pH} 3$ with $1 \mathrm{M} \mathrm{HCl}$. Then the sample was added to the SPE cartridge, which was preconditioned with $1 \mathrm{~mL}$ of methanol, $1 \mathrm{~mL}$ of water, and then $1 \mathrm{~mL}$ of water $(\mathrm{pH}$ 3). After the sample had been loaded, the cartridge was washed with $1 \mathrm{~mL}$ of water and then with $1 \mathrm{~mL}$ of methanol/water $(3: 7, \mathrm{v} / \mathrm{v})$. Then prostanoids were eluted with $1 \mathrm{~mL}$ of methanol. The eluate was dried under a nitrogen gas stream at $25^{\circ} \mathrm{C}$ and the residue was reconstituted in $50 \mu \mathrm{L}$ of mobile phase. 


\subsection{Method validation}

Intra-day precision and accuracy were determined by measuring 6 samples each at low concentrations $(0.5 \mathrm{ng} / \mathrm{mL}$ for extracellular measurement and $0.25 \mathrm{ng}$ for intracellular measurement), intermediate concentrations $(5 \mathrm{ng} / \mathrm{mL}$ for extracellular measurement and $2.5 \mathrm{ng}$ for intracellular measurement), and high concentrations (50 $\mathrm{ng} / \mathrm{mL}$ for extracellular measurement and $25 \mathrm{ng}$ for intracellular measurement) on the same day. Inter-day precision and accuracy were determined by measuring on 6 different days. The relative error (RE \%) was calculated as [(found amount - theoretical amount)/spiked amount] $\times 100(\%)$. For intracellular assay, the RE for analyte which contains the analyte endogenously more than the lower limit of quantification (LLOQ) was calculated as [(found amount - blank amount - theoretical amount)/spiked amount] $\times 100(\%)$. LLOQ was defined as signal-to-noise $(\mathrm{S} / \mathrm{N})$ ratio of $>10$. The precision was obtained as the coefficient of variation (relative standard deviation (R.S.D., \%)). Recovery was measured by spiking known amounts of prostanoids at low $(0.5 \mathrm{ng} / \mathrm{mL}$ for extracellular measurement and $0.25 \mathrm{ng}$ for intracellular measurement), intermediate ( $5 \mathrm{ng} / \mathrm{mL}$ for extracellular measurement and $25 \mathrm{ng}$ for intracellular measurement), and high concentrations $(50 \mathrm{ng} / \mathrm{mL}$ for extracellular measurement and $25 \mathrm{ng}$ for intracellular measurement) into blank medium (for extracellular measurement) or Calu-3 cell pellets (for intracellular measurement), extracting as described above, and comparing with unextracted standards that represent $100 \%$ recovery. For evaluation of short-term stability of prostanoids in medium, we measured remaining amounts after addition of prostanoids to the medium at two concentrations ( 5 and $50 \mathrm{ng} / \mathrm{mL}$ ) at room temperature or $4^{\circ} \mathrm{C}$. For evaluation of long-term stability, we measured remaining amounts after 
storing prostanoids in medium (for extracellular measurement) or in Calu-3 cell pellets (for intracellular measurement) at two concentrations $(2.5$ and $25 \mathrm{ng})$ at $-80^{\circ} \mathrm{C}$.

\section{Results and discussion}

\subsection{LC/MS/MS}

Negative ion full-scan mass spectra (Q1) of prostanoids and internal standards indicated the presence of the deprotonated molecules $[\mathrm{M}-\mathrm{H}]^{-}$as the predominant ion for each compound. Product ion mass spectra of prostanoids and their internal standards were obtained. The product ion mass spectra of the prostanoids are shown in Fig. 1. Murphy et al. reported the mechanisms of the formation of a product ion of each prostanoid in negative ion tandem mass spectrometry [20]. Ion pairs selected for MRM and parameter settings are shown in Table 1. The isomers $\mathrm{PGE}_{2}$ and $\mathrm{PGD}_{2}$ showed similar fragmentation patterns, indicating that chromatographic separation is required for accurate quantification. A Shiseido CAPCELL PAK C18 MGII column was used for chromatographic separation. We investigated several mobile phase conditions such as $\mathrm{pH}$ and organic solvents for simultaneous quantification of the five prostanoids. When the mobile phase methanol or acetonitrile in ammonium acetate buffer $(\mathrm{pH} 8)$ was investigated, the peak of 6-keto $\mathrm{PGF}_{1 \alpha}$ was very low and broad. On the other hand, use of acetonitrile in acidic conditions produced optimal separation with a high degree of sensitivity of all prostanoids. Finally, optimal separation with a high degree of sensitivity was obtained using acetonitrile/water/acetic acid (40:60:0.1, v/v/v) (Fig. 2). The isomers $\mathrm{PGE}_{2}$ and $\mathrm{PGD}_{2}$ were separated by approximately 1 min (resolution $R s=$ 3.2). In comparison with previous studies, the separation efficiency was good despite simple isocratic separation and the run time was short $(12 \mathrm{~min})[7,15]$. 


\subsection{Calibration curve}

For extracellular measurement, calibration standards were prepared in blank medium. For intracellular measurement, calibration standards were prepared in phosphate buffer, the composition of which is described in the Materials and methods section, because cells contain several prostanoids endogenously. As shown in Table 2, calibration curves of the prostanoids for extracellular measurement were linear in the range from 0.1 to $100 \mathrm{ng} / \mathrm{mL}\left(r^{2}>0.999\right)$, and those for intracellular measurement were linear in the range from 0.05 to $50 \mathrm{ng}\left(r^{2}>0.999\right)$.

\subsection{Recovery}

A Bond Elut ${ }^{\circledR}$ C18 disk cartridge was used for extraction of prostanoids. Our extraction procedure produced excellent clean-up results. The recovery from blank medium was measured by spiking known amounts of prostanoids at three different concentrations $(0.5,5$, and $50 \mathrm{ng} / \mathrm{mL})$ into blank medium and comparing the mean peak area ratio with unextracted standards that represent $100 \%$ recovery. Since the cells contain the prostanoids endogenously, the recovery from Calu-3 cell pellets was calculated as [(area ratio of extracted sample - area ratio of blank sample)/area ratio of unextracted standards] $\times 100(\%)$. The recovery from medium ranged from 74.4 to $91.1 \%$ and that from Calu-3 cells ranged from 74.7 to $84.1 \%$. The results are summarized in Table 3.

\subsection{Accuracy and precision}

The intra-day precision and inter-day precision as well as accuracy were tested 
at three different concentrations $(0.5,5$, and $50 \mathrm{ng} / \mathrm{mL}$ for extracellular measurement and $0.25,2.5$, and $5 \mathrm{ng}$ for intracellular measurement). For the extracellular assay, the intra-day precision ranged from 2.3 to $6.5 \%$ and the relative errors were -4.1 to $5.9 \%$. The inter-day precision ranged from 3.2 to $6.8 \%$ and the relative errors were -1.2 to 4.5\% (Table 4). For intracellular assay validation, we used Calu-3 cells and A549 cells. Calu-3 and A549 cells endogenously contain $\mathrm{PGE}_{2}, \mathrm{PGF}_{2 \alpha}$, and $\mathrm{TXB}_{2}$. However, the amounts of prostanoids in Calu-3 validation samples were smaller than the lower limit of quantification (LLOQ). LLOQ was defined as signal-to-noise (S/N) ratio of $>10$. The intra-day precision ranged from 2.2 to $5.7 \%$ and relative errors were -5.8 to $2.3 \%$. The inter-day precision ranged from 3.4 to $13.3 \%$ and relative errors were -1.2 to $7.3 \%$ (Table 5, left). On the other hand, a large amount of $\mathrm{PGE}_{2}$ was detected in A549 cells. Although there were detectable levels of $\mathrm{PGF}_{2 \alpha}$ and $\mathrm{TXB}_{2}$, these amounts of validation samples were less than the LLOQ. The intra-day precision ranged from 1.2 to $9.7 \%$ and relative errors were -3.5 to $14.9 \%$. The inter-day precision ranged from 1.6 to $13.7 \%$ and relative errors were -1.0 to $10.1 \%$ (Table 5 , right). These results indicate that the method of intracellular measurement is highly reliable with good accuracy and precision.

\subsection{Stability}

We examined the stability of prostanoids in cell culture medium or in cell samples. For evaluation of short-term stability of the prostanoids in medium, we measured remaining amounts after addition of prostanoids to the medium at two concentrations ( 5 and $50 \mathrm{ng} / \mathrm{mL}$ ). All prostanoids in the medium were stable for at least 4 hours at room temperature, and all of the prostanoids expect for $\mathrm{PGD}_{2}$ were stable at 
24 hours (Table 6A). The remaining $\mathrm{PGD}_{2}$ in the medium was less than $50 \%$ at 24 hours. Instability of $\mathrm{PGD}_{2}$ was reported previously [7]. However, PGD2 was more stable at $4^{\circ} \mathrm{C}$ than at room temperature. For evaluation of long-term stability, we measured remaining amounts after storing prostanoids in medium (for extracellular measurement) or in Calu-3 cell pellets (for intracellular measurement) at two concentrations ( 5 and 50 $\mathrm{ng} / \mathrm{mL}$ for extracellular measurement, $2.5 \mathrm{ng}$ and $25 \mathrm{ng}$ for intracellular measurement) at $-80^{\circ} \mathrm{C}$ (Table $\left.6 \mathrm{~B}\right)$. The results indicated that all prostanoids both in the medium and in Calu-3 cells were stable for at least 4 weeks at $-80^{\circ} \mathrm{C}$.

\subsection{Intracellular and extracellular prostanoids in Calu-3 and A549 cells}

To test the suitability of the method, we measured prostanoids produced by Calu-3 cells or A549 cells under the condition of stimulation by the calcium ionophore $\mathrm{A} 23187(10 \mu \mathrm{M})$. In A549 cells, the levels of $\mathrm{PGE}_{2}, \mathrm{PGF}_{2 \alpha}$ and $\mathrm{TXB}_{2}$ were larger than LLOQ both in extracellular and intracellular compartments under a non-stimulated condition (Fig. 3A and 3B). The results showing that A549 cells mainly secreted $\mathrm{PGE}_{2}$, $\mathrm{PGF}_{2 \alpha}$ and $\mathrm{TXB}_{2}$ were in agreement with the report by Hubbard et al. [21]. In Table 5, intracellular levels of $\mathrm{PGF}_{2 \alpha}$ and $\mathrm{TXB}_{2}$ were smaller than LLOQ. However, the levels of $\mathrm{PGF}_{2 \alpha}$ and $\mathrm{TXB}_{2}$ under a non-stimulated condition were slightly larger than LLOQ in Fig. 3. Although the levels of $\mathrm{PGF}_{2 \alpha}$ and $\mathrm{TXB}_{2}$ were larger than LLOQ in Fig. 3, those were close to LLOQ. Furthermore, the passage number of A549 cells used in Fig. 3 was different from that in Table 5. Consequently, the endogenous levels of prostanoids might be slightly different between the samples of Table 5 and those of Fig.3. A23187 treatment further increased extracellular levels of these prostanoids, peaking within 5 min at approximately $12 \mathrm{ng} / \mathrm{mL}(34 \mathrm{nM})$ for $\mathrm{PGE}_{2}, 5 \mathrm{ng} / \mathrm{mL}(14 \mathrm{nM})$ for $\mathrm{PGF}_{2 \alpha}$, and 0.8 
$\mathrm{ng} / \mathrm{mL}(2.2 \mathrm{nM})$ for $\mathrm{TXB}_{2}$ (Fig. 3A and 3B). Considering affinities of receptors, the concentrations of these prostanoids in the extracellular space were reasonable [22]. On the other hand, the change in intracellular levels by A23187 was moderate in comparison to the change in extracellular levels. The results indicate the possibility that export of the prostanoids is very rapid. In Calu-3 cells, amounts of all prostanoids were smaller than the LLOQ under the non-stimulated condition both in the extracellular and intracellular compartments. A23187 treatment increased extracellular $\mathrm{PGE}_{2}, \mathrm{PGF}_{2 \alpha}$ and $\mathrm{TXB}_{2}$ levels, peaking at 15-30 min (Fig. 4A and 4B). The results showing that Calu-3 mainly secreted $\mathrm{PGE}_{2}, \mathrm{PGF}_{2 \alpha}$ and $\mathrm{TXB}_{2}$ were also in agreement with the report by Hubbard et al. [19]. The differences between levels of prostanoids produced in A549 cells and Calu- 3 cells may be caused by the expression level of COX-2. The expression level of COX-2 in A549 cells was higher than that in Calu-3 cells (data not shown). A23187 also increased intracellular $\mathrm{PGE}_{2}, \mathrm{PGF}_{2 \alpha}$ and $\mathrm{TXB}_{2}$ levels. Interestingly, it seemed that intracellular $\mathrm{PGF}_{2 \alpha}$ level relative to extracellular level was lower than those of other prostanoids, $\mathrm{PGE}_{2}$ and $\mathrm{TXB}_{2}$, both in Calu-3 cells and $\mathrm{A} 549$ cells. The differences might be due to differences in membrane permeability among these prostanoids. Further investigations to clarify the hypothesis are in progress, and we need to accumulate more information on intracellular levels of the prostanoids by examination of various other cell lines. Furthermore, we need to clarify the reason why the change in intracellular levels of prostanoids was moderate in comparison to the change in extracellular levels.

\section{Conclusion}

We developed a method for simultaneous quantification of the intracellular 
levels of five major prostanoids, $\mathrm{PGE}_{2}, \mathrm{PGD}_{2}, \mathrm{PGF}_{2 \alpha}, 6$-keto $\mathrm{PGF}_{1 \alpha}$ and $\mathrm{TXB}_{2}$, in cultured cells using LC/MS/MS in addition to a method for extracellular measurement. Calibration curves of the prostanoids for extracellular measurement were linear in the range from 0.1 to $100 \mathrm{ng} / \mathrm{mL}\left(r^{2}>0.999\right)$, and those for intracellular measurement were linear in the range from 0.05 to $50 \mathrm{ng}\left(r^{2}>0.999\right)$. Validation assessment showed that the methods were highly reliable with good accuracy and precision. The developed LC/MS/MS assay was able to measure prostanoids in A549 cells and Calu-3 cells. To our knowledge, previous LC/MS/MS methods have not been applied to intracellular measurement. In addition, there are no reports of examination of both intracellular and extracellular levels of multiple prostanoids. Our LC/MS/MS methods and results would contribute to the elucidation of the regulatory mechanism of prostanoid secretion and signaling. We are applying this method to investigate the importance of the export process and control mechanism of prostanoids.

\section{References}

[1] D. Wang, R.N. Dubois, Nat. Rev. Cancer 10 (2010) 181.

[2] A.N. Hata, R.M. Breyer, Pharmacol. Ther. 103 (2004) 147.

[3] K. Yuhki, F. Kojima, H. Kashiwagi, J. Kawabe, T. Fujino, S. Narumiya, F, Ushikubi, Pharmacol. Ther. 129 (2011) 195.

[4] Z.L. Huang, Y. Urade, O. Hayaish, Curr. Opin. Pharmacol. 7 (2007) 33.

[5] J.K. Horton, A.S. Williams, Z. Smith-Phillips, R.C. Martin, G. O'Beirne, Anal. Biochem. 271 (1999) 18.

[6] Z.P. Lin, Y.L. Zhu, D.R. Johnson, K.P. Rice, T. Nottoli, B.C. Hains, J. McGrath, S.G. Waxman, A.C. Sartorelli, Mol. Pharmacol. 73 (2008) 243. 
[7] H. Cao, L. Xiao, G. Park, X. Wang, A.C. Azim, J.W. Christman, R.B. van Breemen, Anal. Biochem. 372 (2008) 41.

[8] M. Takabatake, T. Hishinuma, N. Suzuki, S. Chiba, H. Tsukamoto, H. Nakamura, T. Saga, Y. Tomioka, A. Kurose, T. Sawai, M. Mizugaki, Prostaglandins Leukot. Essent. Fatty Acids 67 (2002) 51.

[9] T. Hishinuma, K. Suzuki, M. Saito, H. Yamaguchi, N. Suzuki, Y. Tomioka, I. Kaneko, M. Ono, J. Goto, Prostaglandins Leukot. Essent. Fatty Acids 76 (2007) 321. [10] P. Yang, D. Chan, E. Felix, T. Madden, R.D. Klein, I. Shureiqi, X. Chen, A.J. Dannenberg, R.A. Newman, Prostaglandins Leukot. Essent. Fatty Acids 75 (2006) 385. [11] G.P. Chappell, X. Xiao, A. Pica-Mendez, T. Varnell, S. Green, W.K. Tanaka, O. Laterza, J. Chromatogr. B Analyt. Technol. Biomed. Life Sci. 879 (2011) 277.

[12] K. Nithipatikom, N.D. Laabs, M.A. Isbell, W.B. Campbell, J. Chromatogr. B Analyt. Technol. Biomed. Life Sci. 785 (2003) 135.

[13] R. Schmidt, O. Coste, G. Geisslinger, J. Chromatogr. B Analyt. Technol. Biomed. Life Sci. 826 (2005) 188.

[14] M. Armstrong, A.H. Liu, R. Harbeck, R. Reisdorph, N. Rabinovitch, N. Reisdorph, J. Chromatogr. B Analyt. Technol. Biomed. Life Sci. 877 (2009) 3169.

[15] M.Y. Golovko, E.J. Murphy, J. Lipid Res. 49 (2008) 893-902.

[16] P. Montuschi, J. Chromatogr. B Analyt. Technol. Biomed. Life Sci. 877 (2009) 1272.

[17] M.B. Willey, W.E. Alborn, B.S. Lutzke, R.M. Lelacheur, R.J. White, G. Stavrakis, R.J. Konrad, B.L. Ackermann, J. Pharm. Biomed. Anal. 48 (2008) 1397.

[18] M. Mal, P. K. Koh, P. Y. Cheah, E. C. Chan. Rapid Commun. Mass Spectrom. 25 (2011) 755 . 
[19] M. Masoodi, M. Eiden, A. Koulman, D. Spaner, D. A. Volmer. Anal. Chem. 82 (2010) 8176.

[20] R.C. Murphy, R.M. Barkley, K. Zemski Berry, J. Hankin, K. Harrison, C. Johnson , J. Krank, A. McAnoy, C. Uhlson, S. Zarini, Anal. Biochem. 346 (2005) 1.

[21] W.C. Hubbard, M.C. Alley, T.L. McLemore, M.R. Boyd, Cancer Res. 48 (1988) 2674.

[22] M. Abramovitz, M. Adam, Y. Boie, M. Carrière, D. Denis, C. Godbout, S. Lamontagne, C. Rochette, N. Sawyer, N.M. Tremblay, M. Belley, M. Gallant, C. Dufresne, Y. Gareau, R. Ruel, H. Juteau, M. Labelle, N. Ouimet, K.M. Metters, Biochim. Biophys. Acta 1483 (2000) 285. 


\section{Figure legends}

Fig. 1 Product ion mass spectra of $\mathrm{PGE}_{2}, \mathrm{PGD}_{2}, \mathrm{PGF}_{2 \alpha}$, 6-keto $\mathrm{PGF}_{1 \alpha}$, and $\mathrm{TXB}_{2}$.

Fig. 2 Representative MRM chromatograms of the prostanoids and their internal standards (IS). A mixture of $\mathrm{PGE}_{2}, \mathrm{PGD}_{2}, \mathrm{PGF}_{2 \alpha}, 6$-keto $\mathrm{PGF}_{1 \alpha}$, and $\mathrm{TXB}_{2}$ standards at $5 \mathrm{ng} / \mathrm{mL}$ containing each IS was extracted using a SPE cartridge and separated by a $\mathrm{C}_{18}$ column with an isocratic flow of acetonitrile/water/acetic acid (40:60:0.1, v/v/v).

Fig. 3 Effects of calcium ionophore A23187 on extracellular and intracellular amounts of prostanoids in A549 cells. (A) A549 cells were treated with $1 \mathrm{~mL}$ of serum-free medium containing A23187 $(10 \mu \mathrm{M})$ or serum-free medium containing 0.2\% DMSO (control) for indicated times $(0.5,1,3$, and $5 \mathrm{~min})$. Each point represents the mean \pm S.D. of three determinations. ○, Control (extracellular level); •, A23187 (extracellular level); $\square$, Control (intracellular level); $\mathbf{~ , ~ A 2 3 1 8 7 ~ ( i n t r a c e l l u l a r ~ l e v e l ) . ~ ( B ) ~}$ Representative chromatograms in A549 cell samples unstimulated or stimulated with A23187 $(10 \mu \mathrm{M})$ at 5 min. A549 cells mainly produced $\mathrm{PGE}_{2}, \mathrm{PGF}_{2 \alpha}$ and $\mathrm{TXB}_{2}$.

Fig. 4 Effects of calcium ionophore A23187 on extracellular and intracellular amounts of prostanoids in Calu-3 cells. (A) Calu-3 cells were treated with $1 \mathrm{~mL}$ of serum-free medium containing A23187 $(10 \mu \mathrm{M})$ or serum-free medium containing $0.2 \%$ DMSO (control) for indicated times $(5,15,30$, and $60 \mathrm{~min})$. Each point represents the mean \pm S.D. of three determinations. •, A23187 (extracellular level); 匹, A23187 (intracellular level). (B) Representative chromatograms in Calu-3 cell samples unstimulated or stimulated with A23187 $(10 \mu \mathrm{M})$ at 5 min. Calu-3 cells mainly produced $\mathrm{PGE}_{2}, \mathrm{PGF}_{2 \alpha}$ 
and $\mathrm{TXB}_{2}$ by stimulation with $\mathrm{A} 23187$. 
Table 1 MRM parameters for determination of prostanoids

\begin{tabular}{lcccc}
\hline \multicolumn{1}{c}{ Analyte } & Precursor ion $(\mathrm{m} / \mathrm{z})$ & Product ion $(\mathrm{m} / \mathrm{z})$ & $\mathrm{DP}(\mathrm{V})$ & $\mathrm{CE}(\mathrm{V})$ \\
\hline $\mathrm{PGE}_{2}$ & 351 & 271 & -30 & -16 \\
$\mathrm{PGE}_{2}-\mathrm{d}_{4}$ & 355 & 275 & -30 & -16 \\
$\mathrm{PGD}_{2}$ & 351 & 271 & -30 & -16 \\
$\mathrm{PGD}_{2}-\mathrm{d}_{4}$ & 355 & 275 & -30 & -16 \\
$\mathrm{PGF}_{2 \alpha}$ & 353 & 193 & -50 & -40 \\
$\mathrm{PGF}_{2 \alpha}-\mathrm{d}_{4}$ & 357 & 197 & -50 & -40 \\
$6-\mathrm{keto}_{\mathrm{PGF}}$ & 369 & 163 & -40 & -38 \\
$6-\mathrm{keto}_{1 \alpha} \mathrm{PGF}_{1 \alpha}-\mathrm{d}_{4}$ & 373 & 167 & -40 & -38 \\
$\mathrm{TXB}_{2}$ & 369 & 169 & -35 & -24 \\
$\mathrm{TXB}_{2}-\mathrm{d}_{4}$ & 373 & 173 & -35 & -24 \\
\hline
\end{tabular}


Table 2 Calibration curves for the prostanoids

\begin{tabular}{|c|c|c|c|c|c|c|c|c|}
\hline \multirow[b]{2}{*}{ Analyte } & \multicolumn{4}{|c|}{ Extracellular measurement } & \multicolumn{4}{|c|}{ Intracellular measurement } \\
\hline & Range (ng/mL) & Slope & Intercept & $r$ & Range (ng) & Slope & Intercept & $r$ \\
\hline $\mathrm{PGE}_{2}$ & $0.1-100$ & 0.398 & 0.00931 & 0.9999 & $0.05-50$ & 0.868 & 0.00113 & 0.9997 \\
\hline $\mathrm{PGD}_{2}$ & $0.1-100$ & 0.359 & -0.0016 & 1.0000 & $0.05-50$ & 0.735 & -0.00787 & 0.9996 \\
\hline $\mathrm{PGF}_{2 \alpha}$ & $0.1-100$ & 0.315 & 0.0255 & 1.0000 & $0.05-50$ & 0.675 & 0.0112 & 0.9998 \\
\hline 6-keto $\mathrm{PGF}_{1 \alpha}$ & $0.1-100$ & 0.269 & 0.0184 & 1.0000 & $0.05-50$ & 0.590 & 0.0067 & 0.9999 \\
\hline $\mathrm{TXB}_{2}$ & $0.1-100$ & 0.174 & 0.00677 & 0.9999 & $0.05-50$ & 0.380 & 0.00455 & 0.9999 \\
\hline
\end{tabular}


Table 3 Absolute recoveries of prostanoids

\begin{tabular}{lcccccccc}
\hline & \multicolumn{3}{c}{ Medium (\%) } & & \multicolumn{3}{c}{ Calu-3 cells (\%) } \\
\cline { 2 - 4 } \cline { 6 - 8 } \cline { 6 - 8 } \cline { 6 - 8 } & $0.5 \mathrm{ng} / \mathrm{mL}$ & $5 \mathrm{ng} / \mathrm{mL}$ & $50 \mathrm{ng} / \mathrm{mL}$ & & $0.25 \mathrm{ng}$ & $2.5 \mathrm{ng}$ & $25 \mathrm{ng}$ \\
\hline $\mathrm{PGE}_{2}$ & 75.8 & 79.0 & 80.9 & & 80.5 & 82.4 & 79.1 \\
$\mathrm{PGD}_{2}$ & 74.4 & 77.1 & 78.4 & & 81.5 & 79.6 & 74.7 \\
$\mathrm{PGF}_{2 \alpha}$ & 85.1 & 81.5 & 83.9 & & 78.8 & 84.1 & 77.7 \\
6-keto PGF & 81.0 & 80.8 & 83.0 & & 78.6 & 85.0 & 81.1 \\
$\mathrm{TXB}_{2}$ & 91.1 & 81.8 & 85.3 & & 82.2 & 80.2 & 76.6 \\
\hline
\end{tabular}


Table 4 Intra-day and inter-day reproducibility of the prostanoids in medium (extracellular measurement)

\begin{tabular}{|c|c|c|c|c|c|c|c|}
\hline & \multirow[b]{2}{*}{$\begin{array}{l}\text { Spiked } \\
(\mathrm{ng} / \mathrm{mL})\end{array}$} & \multicolumn{3}{|c|}{ Intra-day $(\mathrm{n}=6)$} & \multicolumn{3}{|c|}{ Inter-day $(n=6)$} \\
\hline & & $\begin{array}{l}\text { Found } \\
\text { (ng/mL) }\end{array}$ & $\begin{array}{c}\text { R.S.D. } \\
(\%)\end{array}$ & $\begin{array}{l}\text { R.E. } \\
(\%)\end{array}$ & $\begin{array}{l}\text { Found } \\
\text { (ng/mL) }\end{array}$ & $\begin{array}{c}\text { R.S.D. } \\
(\%)\end{array}$ & $\begin{array}{r}\text { R.E. } \\
(\%)\end{array}$ \\
\hline \multirow{3}{*}{$\mathrm{PGE}_{2}$} & 0.5 & 0.492 & 2.5 & -1.7 & 0.515 & 3.2 & 2.9 \\
\hline & 5 & 4.90 & 2.9 & -1.9 & 5.11 & 5.3 & 2.2 \\
\hline & 50 & 48.0 & 3.2 & -4.1 & 51.4 & 6.2 & 2.7 \\
\hline \multirow{3}{*}{$\mathrm{PGD}_{2}$} & 0.5 & 0.496 & 6.5 & -0.9 & 0.523 & 6.3 & 4.5 \\
\hline & 5 & 4.86 & 3.5 & -2.8 & 4.98 & 6.0 & -0.4 \\
\hline & 50 & 49.1 & 2.3 & -1.8 & 51.0 & 4.9 & 1.9 \\
\hline \multirow{3}{*}{$\mathrm{PGF}_{2 \alpha}$} & 0.5 & 0.496 & 2.9 & -0.8 & 0.506 & 4.7 & 1.3 \\
\hline & 5 & 4.95 & 4.5 & -1.0 & 5.02 & 5.8 & 0.4 \\
\hline & 50 & 49.3 & 4.1 & -1.5 & 51.1 & 5.9 & 2.1 \\
\hline \multirow{3}{*}{ 6-keto $\mathrm{PGF}_{1 \alpha}$} & 0.5 & 0.491 & 5.6 & -1.9 & 0.504 & 5.8 & 0.8 \\
\hline & 5 & 4.82 & 3.5 & -3.5 & 4.98 & 3.7 & -0.4 \\
\hline & 50 & 48.1 & 3.3 & -3.7 & 50.9 & 6.8 & 1.7 \\
\hline \multirow{3}{*}{$\mathrm{TXB}_{2}$} & 0.5 & 0.530 & 3.4 & 5.9 & 0.511 & 4.5 & 2.2 \\
\hline & 5 & 4.91 & 3.7 & -1.9 & 4.94 & 3.9 & -1.2 \\
\hline & 50 & 48.5 & 3.1 & -3.1 & 51.3 & 5.1 & 2.6 \\
\hline
\end{tabular}


Table 5 Intra-day and inter-day reproducibility of the prostanoids in Calu-3 cells or A549 cells (intracellular measurement)

\begin{tabular}{|c|c|c|c|c|c|c|c|c|c|c|c|c|c|}
\hline & \multirow[b]{3}{*}{ Spiked } & \multicolumn{6}{|c|}{ Calu-3 } & \multicolumn{6}{|c|}{ A549 } \\
\hline & & \multicolumn{3}{|c|}{ Intra-day $(n=6)$} & \multicolumn{3}{|c|}{ Inter-day $(n=6)$} & \multicolumn{3}{|c|}{ Intra-day $(n=6)$} & \multicolumn{3}{|c|}{ Inter-day $(n=6)$} \\
\hline & & $\begin{array}{c}\text { Found } \\
\text { (ng) }\end{array}$ & $\begin{array}{c}\text { R.S.D. } \\
(\%)\end{array}$ & $\begin{array}{l}\text { R.E. } \\
(\%)\end{array}$ & $\begin{array}{c}\text { Found } \\
\text { (ng) }\end{array}$ & $\begin{array}{c}\text { R.S.D. } \\
(\%)\end{array}$ & $\begin{array}{l}\text { R.E. } \\
(\%) \\
\end{array}$ & $\begin{array}{c}\text { Found } \\
\text { (ng) }\end{array}$ & $\begin{array}{c}\text { R.S.D. } \\
(\%)\end{array}$ & $\begin{array}{l}\text { R.E. } \\
(\%)\end{array}$ & $\begin{array}{c}\text { Found } \\
\text { (ng) }\end{array}$ & $\begin{array}{c}\text { R.S.D. } \\
(\%)\end{array}$ & $\begin{array}{l}\text { R.E. } \\
(\%) \\
\end{array}$ \\
\hline \multirow{4}{*}{$\mathrm{PGE}_{2}$} & 0 & $<$ LLOQ & - & - & $<$ LLOQ & - & - & 0.817 & - & - & 0.734 & - & - \\
\hline & 0.25 & 0.248 & 2.2 & -0.6 & 0.268 & 12.5 & 7.3 & 1.10 & 9.7 & 13.3 & 0.991 & 13.7 & 2.7 \\
\hline & 2.5 & 2.46 & 2.4 & -1.8 & 2.58 & 6.4 & 3.4 & 3.50 & 4.6 & 7.4 & 3.34 & 5.9 & 4.1 \\
\hline & 25 & 24.1 & 3.1 & -3.8 & 25.1 & 3.4 & 0.4 & 27.3 & 2.5 & 6.1 & 26.7 & 2.8 & 4.0 \\
\hline \multirow{4}{*}{$\mathrm{PGD}_{2}$} & 0 & $<$ LLOQ & - & - & $<$ LLOQ & - & - & $<$ LLOQ & - & - & $<$ LLOQ & - & - \\
\hline & 0.25 & 0.247 & 5.0 & -1.1 & 0.250 & 13.3 & 0.1 & 0.273 & 4.6 & 9.1 & 0.253 & 1.6 & 1.3 \\
\hline & 2.5 & 2.43 & 4.8 & -2.9 & 2.46 & 6.5 & -1.6 & 2.41 & 4.6 & -3.5 & 2.48 & 8.7 & -1.0 \\
\hline & 25 & 24.1 & 5.7 & -3.7 & 24.9 & 6.8 & -0.5 & 25.9 & 5.1 & 3.6 & 25.6 & 4.7 & 2.2 \\
\hline \multirow{4}{*}{$\mathrm{PGF}_{2 \alpha}$} & 0 & $<$ LLOQ & - & - & $<$ LLOQ & - & - & $<$ LLOQ & - & - & $<$ LLOQ & - & - \\
\hline & 0.25 & 0.246 & 4.9 & -1.5 & 0.253 & 8.8 & 1.1 & 0.287 & 3.6 & 14.9 & 0.275 & 6.9 & 10.1 \\
\hline & 2.5 & 2.53 & 2.7 & 1.1 & 2.51 & 7.2 & 0.3 & 2.67 & 2.4 & 6.7 & 2.58 & 4.3 & 3.0 \\
\hline & 25 & 24.1 & 5.0 & -3.8 & 24.8 & 4.8 & -0.7 & 26.0 & 2.4 & 3.8 & 26.1 & 3.8 & 4.5 \\
\hline \multirow{4}{*}{ 6-keto $\mathrm{PGF}_{1 \alpha}$} & 0 & $<$ LLOQ & - & - & $<$ LLOQ & - & - & $<$ LLOQ & - & - & $<$ LLOQ & - & - \\
\hline & 0.25 & 0.256 & 2.5 & 2.3 & 0.244 & 10.1 & -2.3 & 0.272 & 3.7 & 8.6 & 0.256 & 5.7 & 2.5 \\
\hline & 2.5 & 2.49 & 2.5 & -6.4 & 2.505 & 7.1 & 0.2 & 2.65 & 2.7 & 6.0 & 2.62 & 2.9 & 4.9 \\
\hline & 25 & 24.0 & 4.2 & -4.2 & 24.8 & 4.2 & -1.0 & 25.9 & 1.2 & 3.6 & 26.0 & 4.5 & 3.9 \\
\hline \multirow{4}{*}{$\mathrm{TXB}_{2}$} & 0 & $<$ LLOQ & - & - & $<$ LLOQ & - & - & $<$ LLOQ & - & - & $<$ LLOQ & - & - \\
\hline & 0.25 & 0.240 & 2.3 & -4.1 & 0.256 & 8.8 & 2.6 & 0.272 & 5.1 & 8.7 & 0.266 & 6.3 & 6.5 \\
\hline & 2.5 & 2.45 & 2.9 & -2.8 & 2.52 & 7.3 & 0.6 & 2.53 & 2.1 & 1.2 & 2.54 & 2.8 & 1.6 \\
\hline & 25 & 23.6 & 3.7 & -5.8 & 24.7 & 4.7 & -1.2 & 25.5 & 2.2 & 1.8 & 25.8 & 2.7 & 3.3 \\
\hline
\end{tabular}


Table 6A Short-term stability of the prostanoids in medium at room temperature or $4^{\circ} \mathrm{C}$

\begin{tabular}{|c|c|c|c|c|c|}
\hline & & \multicolumn{4}{|c|}{ Short-term stability (\% remaining) } \\
\hline & & \multicolumn{2}{|c|}{ Room temperature } & \multicolumn{2}{|c|}{$4^{\circ} \mathrm{C}$} \\
\hline & & $5 \mathrm{ng} / \mathrm{mL}$ & $50 \mathrm{ng} / \mathrm{mL}$ & $5 \mathrm{ng} / \mathrm{mL}$ & $50 \mathrm{ng} / \mathrm{mL}$ \\
\hline \multirow{2}{*}{$\mathrm{PGE}_{2}$} & $4 \mathrm{~h}$ & 104.2 & 102.7 & 93.4 & 93.5 \\
\hline & $24 \mathrm{~h}$ & 97.0 & 90.3 & 104.1 & 100.1 \\
\hline \multirow{2}{*}{$\mathrm{PGD}_{2}$} & $4 \mathrm{~h}$ & 93.9 & 93.6 & 91.5 & 89.3 \\
\hline & $24 \mathrm{~h}$ & 49.3 & 46.9 & 85.7 & 82.9 \\
\hline \multirow{2}{*}{$\mathrm{PGF}_{2 \alpha}$} & $4 \mathrm{~h}$ & 108.9 & 103.2 & 95.3 & 94.8 \\
\hline & $24 \mathrm{~h}$ & 101.6 & 97.1 & 99.6 & 97.1 \\
\hline 6-keto & $4 \mathrm{~h}$ & 103.0 & 99.9 & 93.3 & 90.9 \\
\hline $\mathrm{PGF}_{1 \alpha}$ & $24 \mathrm{~h}$ & 106.6 & 99.5 & 102.3 & 97.9 \\
\hline \multirow{2}{*}{$\mathrm{TXB}_{2}$} & $4 \mathrm{~h}$ & 102.9 & 102.4 & 95.5 & 94.1 \\
\hline & $24 \mathrm{~h}$ & 110.6 & 99.4 & 102.7 & 98.5 \\
\hline
\end{tabular}

Table 6B Long-term stability of the prostanoids at $-80^{\circ} \mathrm{C}$

\begin{tabular}{|c|c|c|c|c|c|}
\hline & & \multicolumn{4}{|c|}{ Long-term stability (\% remaining) } \\
\hline & & \multicolumn{2}{|c|}{ in medium } & \multicolumn{2}{|c|}{ in Calu-3 cells } \\
\hline & & $5 \mathrm{ng} / \mathrm{mL}$ & $50 \mathrm{ng} / \mathrm{mL}$ & $2.5 \mathrm{ng}$ & $25 \mathrm{ng}$ \\
\hline \multirow{2}{*}{$\mathrm{PGE}_{2}$} & 2 weeks & 95.7 & 104.4 & 109.3 & 109.2 \\
\hline & 4 weeks & 100.3 & 104.2 & 99.7 & 103.2 \\
\hline \multirow{2}{*}{$\mathrm{PGD}_{2}$} & 2 weeks & 93.6 & 97.9 & 110.5 & 111.8 \\
\hline & 4 weeks & 94.9 & 101.1 & 104.4 & 105.3 \\
\hline \multirow{2}{*}{$\mathrm{PGF}_{2 \alpha}$} & 2 weeks & 93.1 & 100.5 & 110.2 & 109.1 \\
\hline & 4 weeks & 100.9 & 105.9 & 101.5 & 99.7 \\
\hline 6-keto & 2 weeks & 93.4 & 101.4 & 110.9 & 111.4 \\
\hline $\mathrm{PGF}_{1 \alpha}$ & 4 weeks & 95.4 & 102.7 & 102.2 & 101.4 \\
\hline \multirow{2}{*}{$\mathrm{TXB}_{2}$} & 2 weeks & 98.5 & 104.4 & 107.3 & 108.1 \\
\hline & 4 weeks & 97.9 & 104.3 & 99.1 & 100.5 \\
\hline
\end{tabular}


Fig. 1
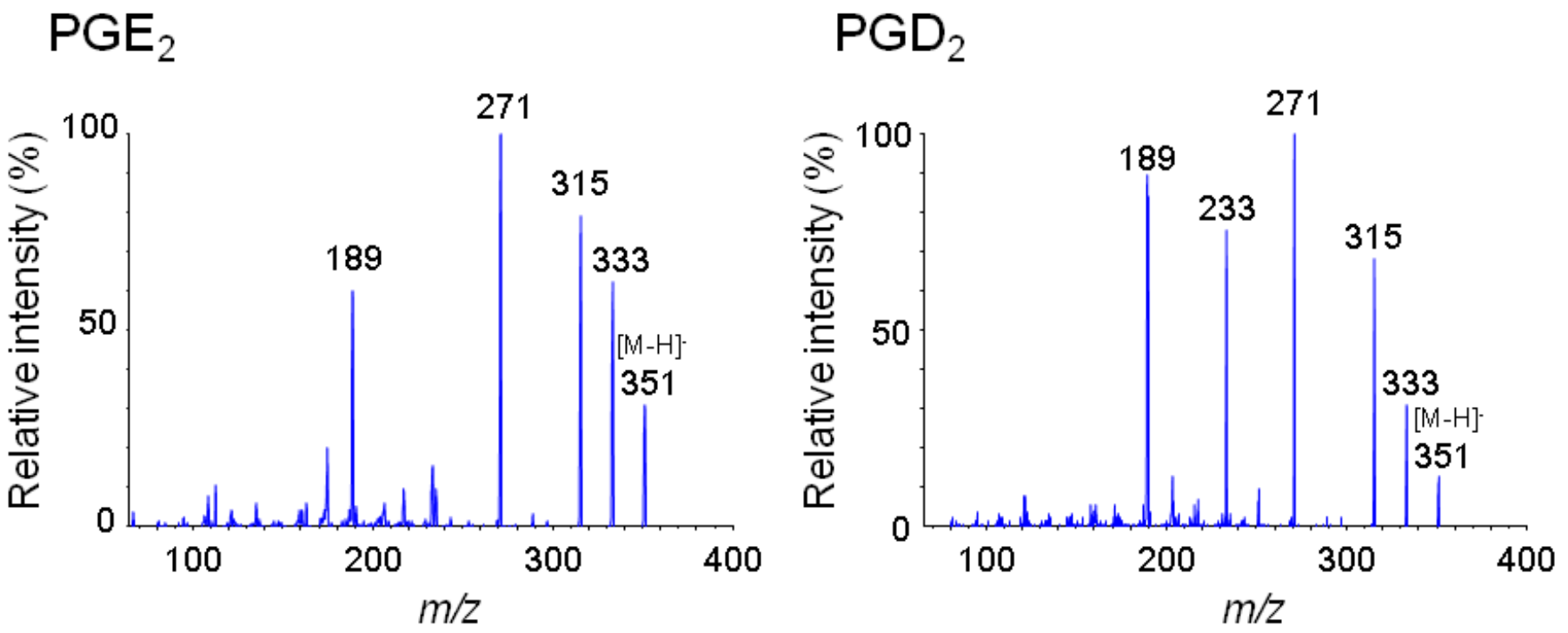

PGF $_{2 a}$

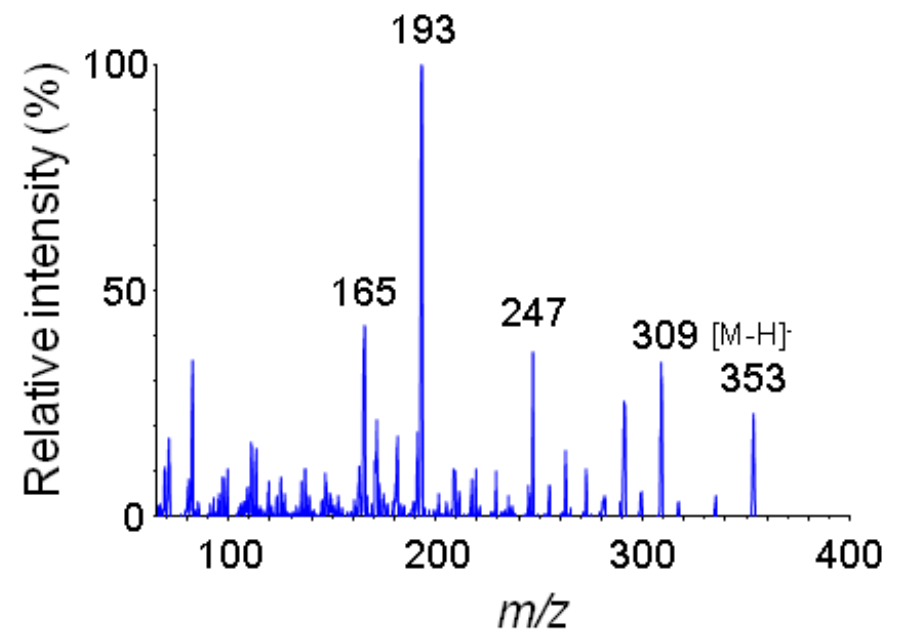

\section{6-keto $\mathrm{PGF}_{1 a}$}

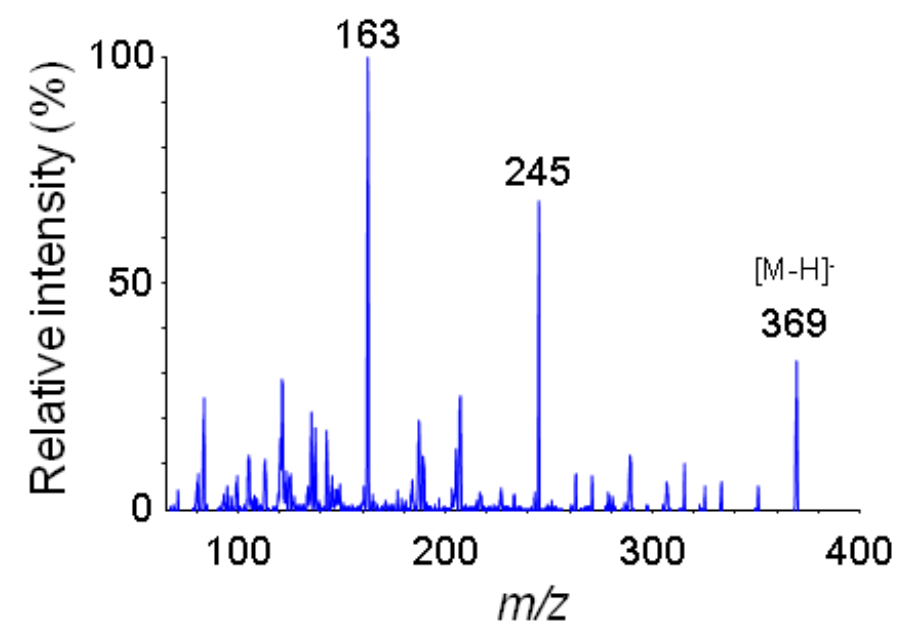

\section{$\mathrm{TXB}_{2}$}

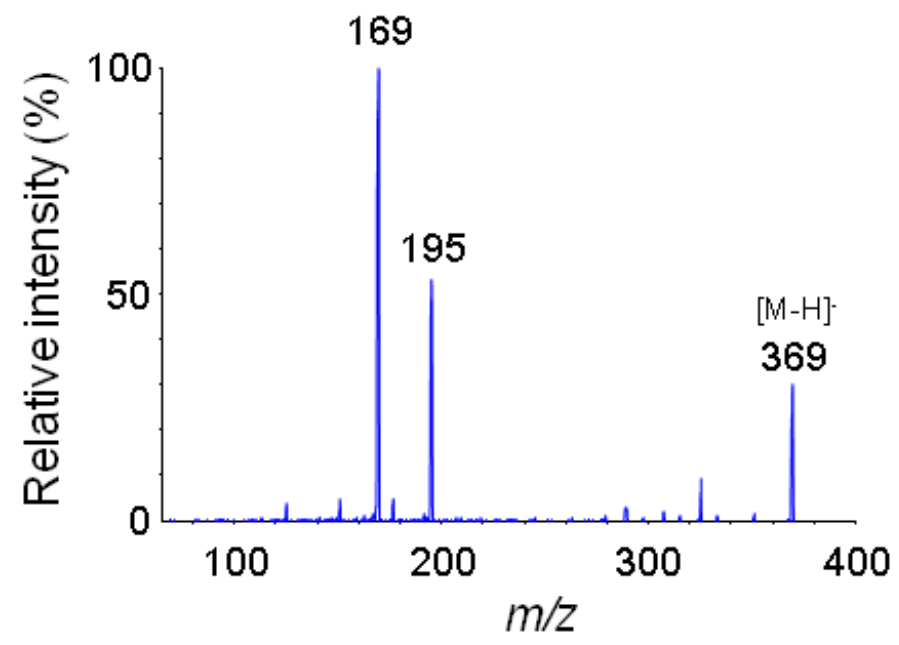


Fig. 2

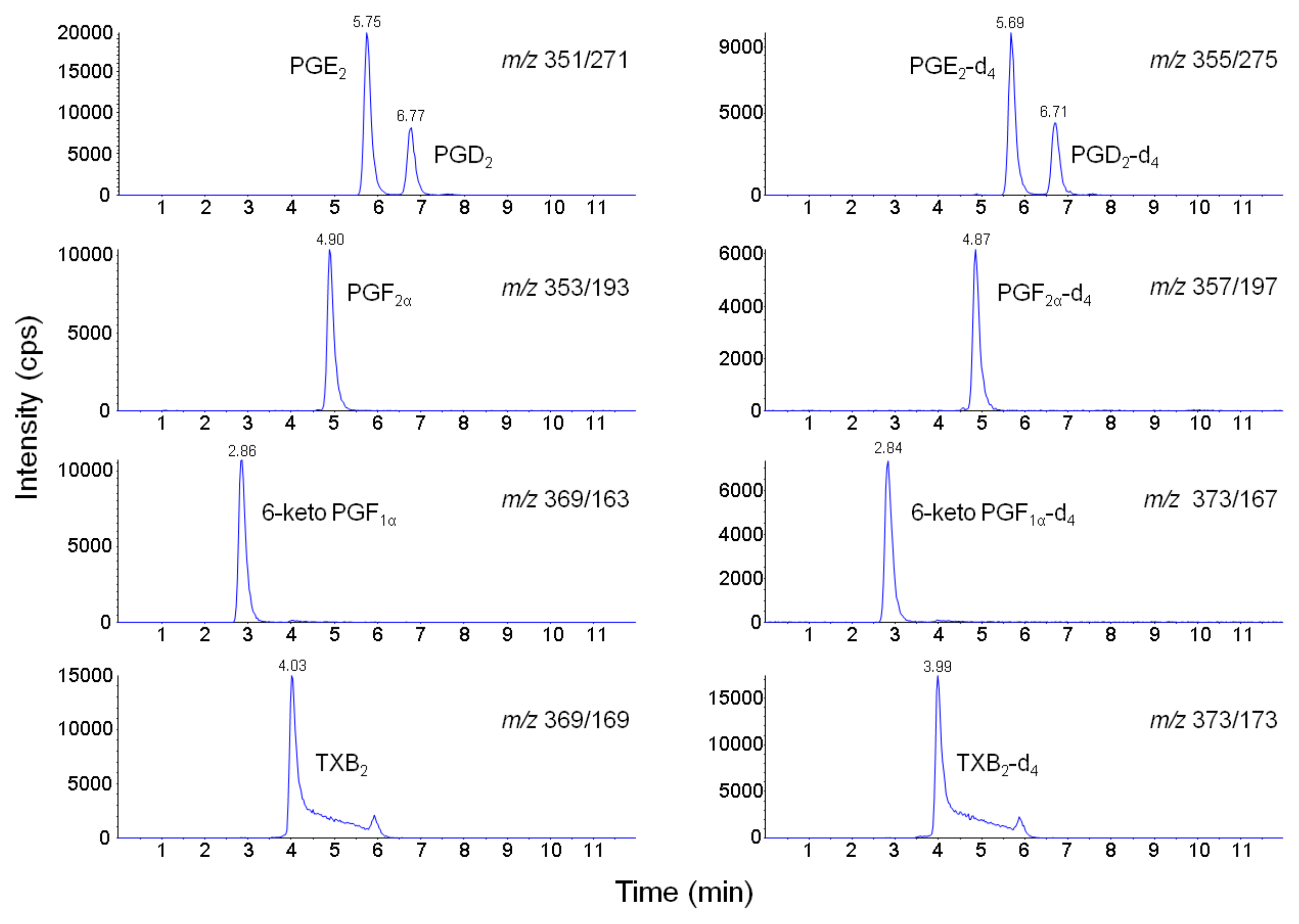



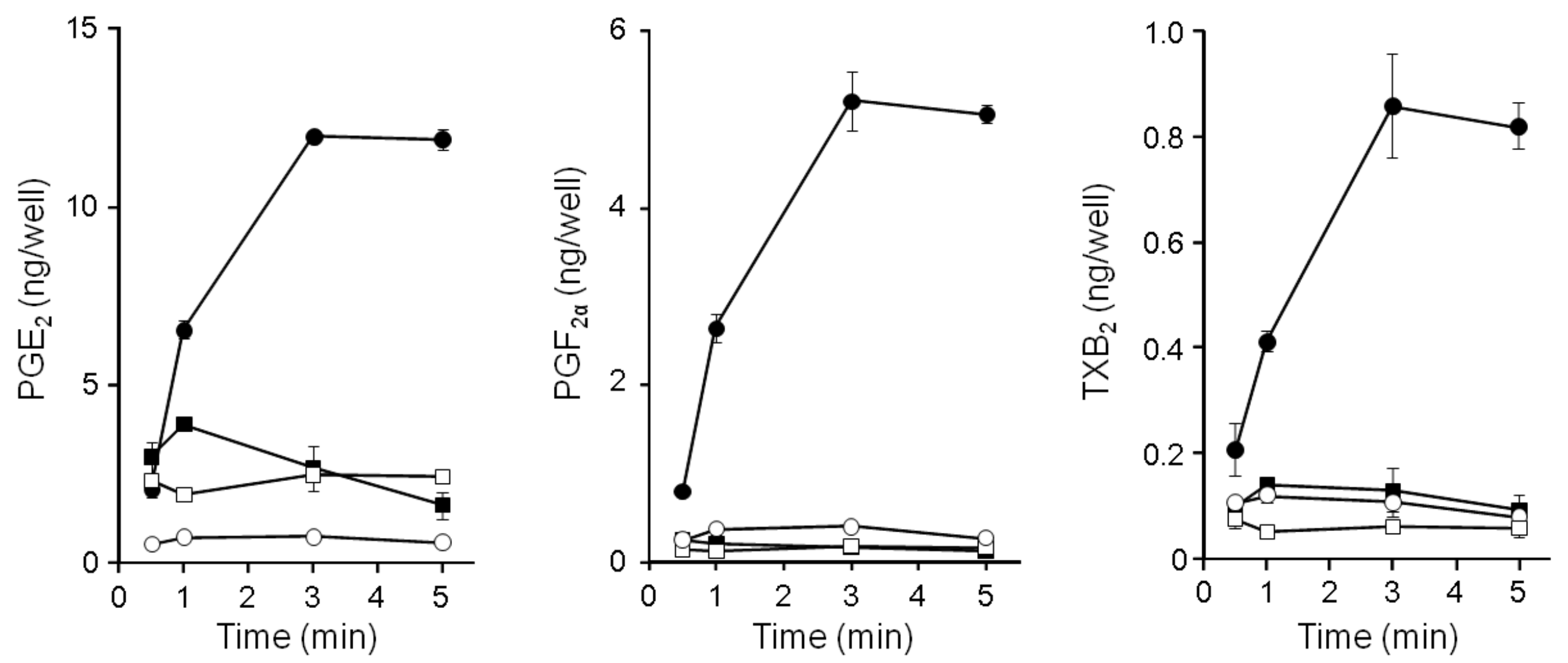
Fig. 3B

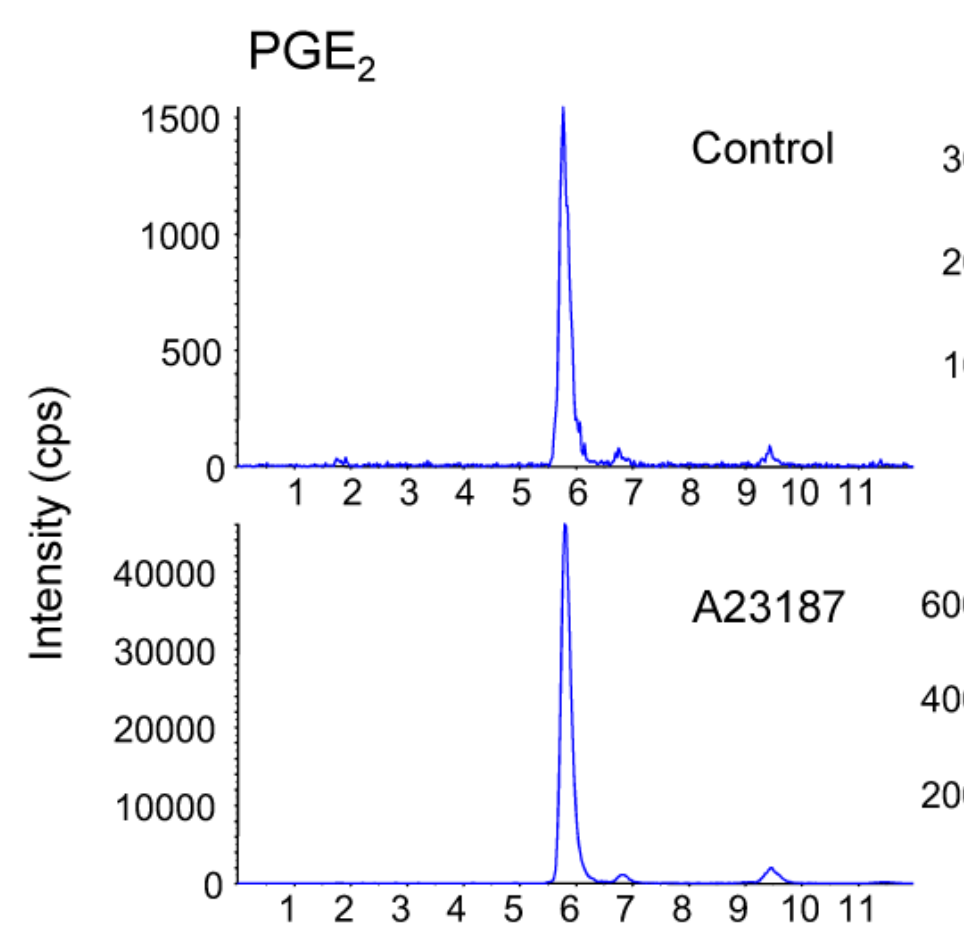

$\mathrm{PGF}_{2 \alpha}$
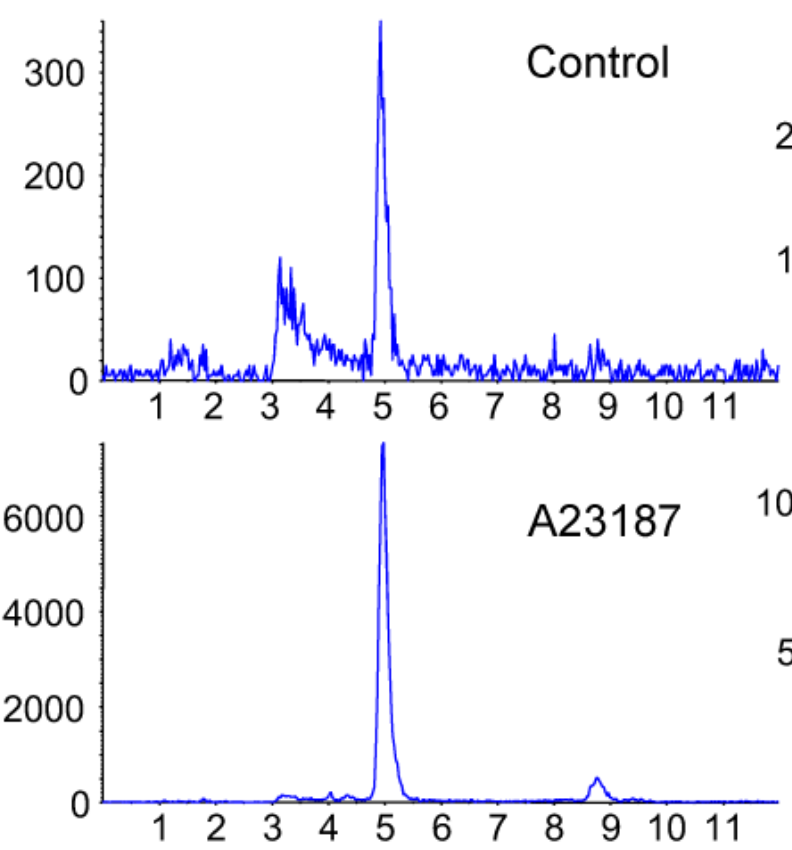

Time (min)
Control

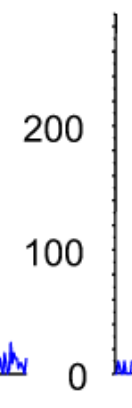

$\mathrm{TXB}_{2}$

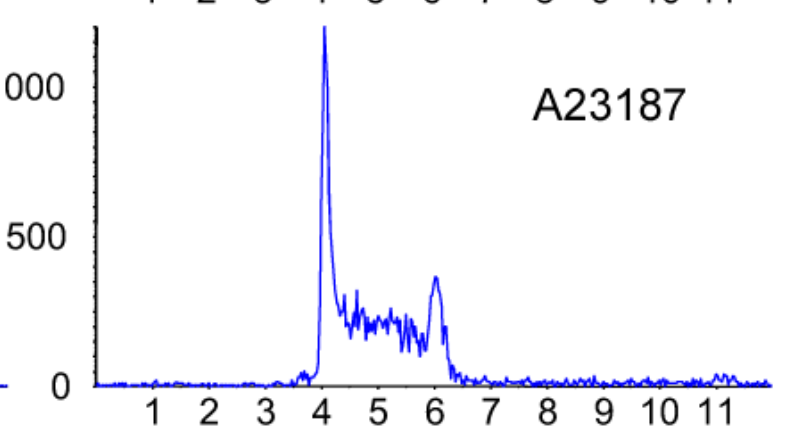

Intracellular measurement
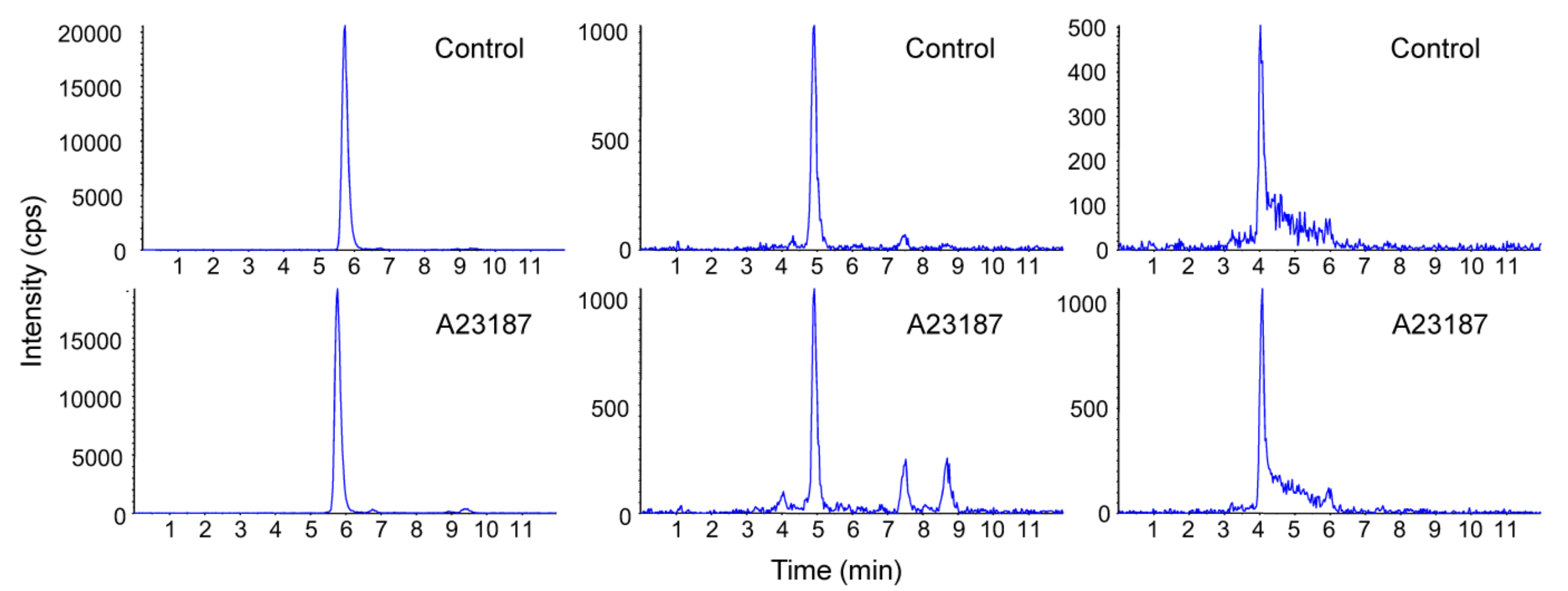
Fig. 4A
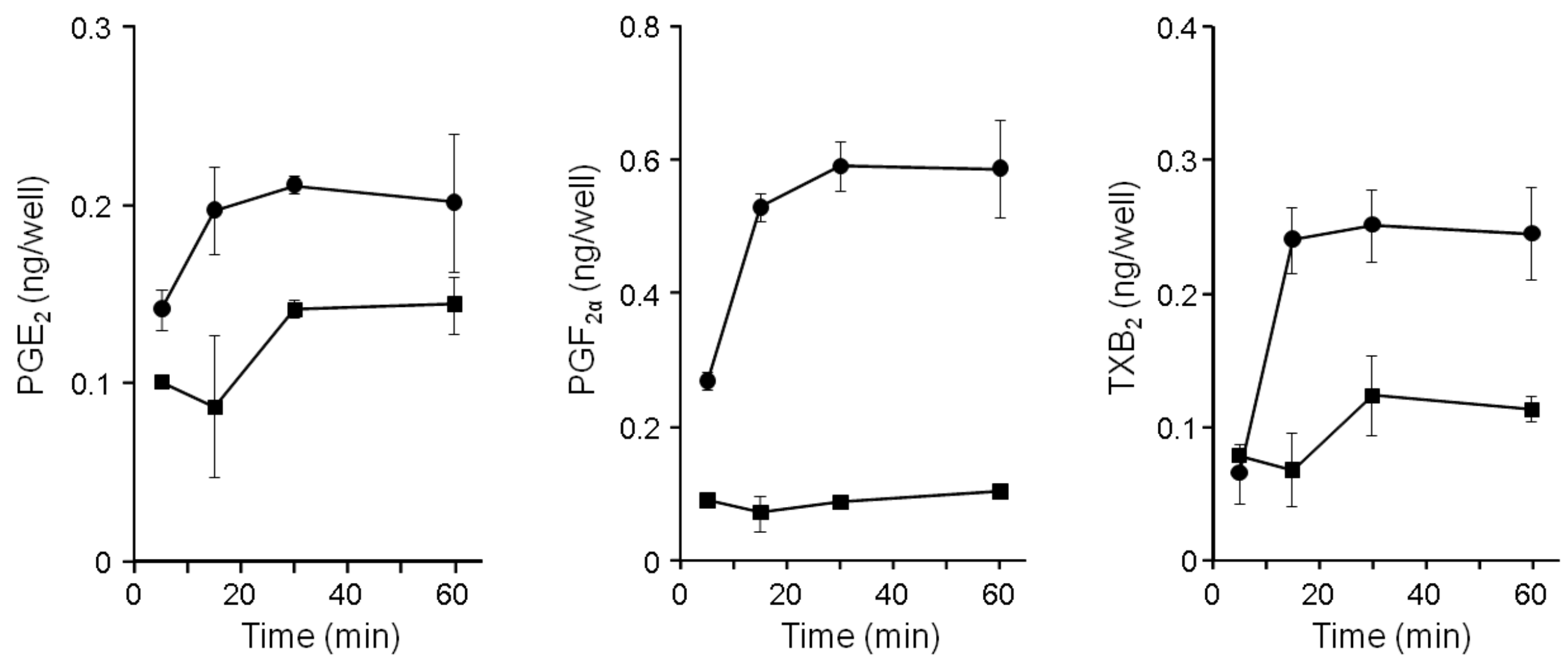
measurement
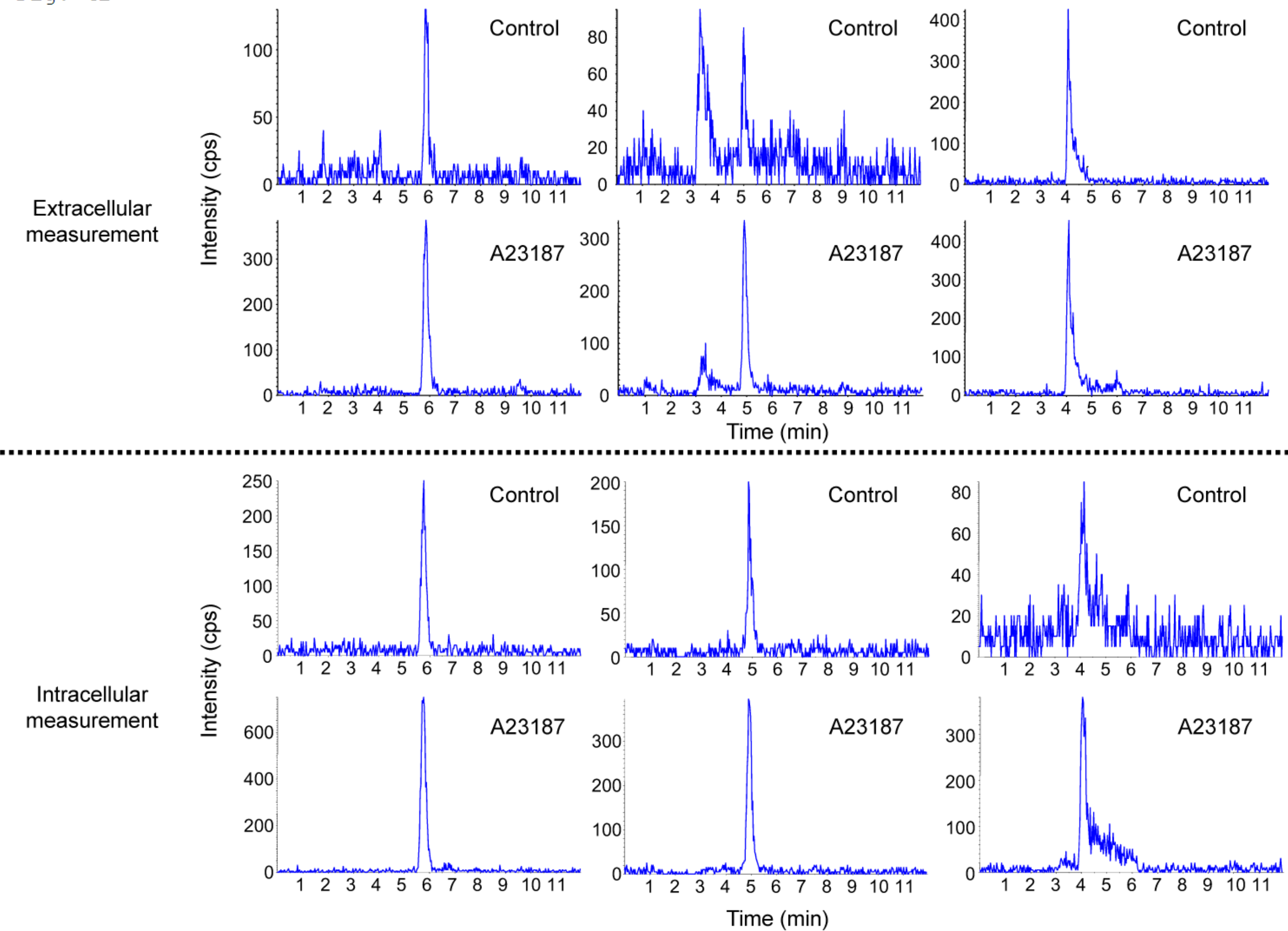